\title{
Return of spontaneous circulation and heart rhythm during the first analysis of the heart electrical activity
}

Nagły powrót krążenia i rytmu serca podczas pierwszej analizy aktywności elektrycznej serca

\section{Sebastian Kowalski ${ }^{1}$, Adrian Moskall, Karolina Żak-Kowalska ${ }^{2}$, Mariusz Goniewicz ${ }^{1}$}

\author{
'Department of Emergency Medicine, Medical University of Lublin, Lublin, Poland/ \\ Zakład Ratownictwa Medycznego, Uniwersytet Medyczne w Lublinie, Polska \\ ${ }^{2}$ Clinical Hospital of Rzeszow, Rzeszow, Poland/Szpital Kliniczny w Rzeszowie, Polska
}

Sebastian Kowalski: 0000-0003-0826-6025 Adrian Moskal: 0000-0002-4061-5275

Karolina Żak-Kowalska: 0000-0003-3772-4275

Mariusz Goniewicz: 0000-0002-3004-6195

CORRESPONDING AUTHOR:

Sebastian Kowalski

Zakład Ratownictwa Medycznego, UM w Lublinie

20-081 Lublin ul. Staszica 4-6

tel. +48814486830

e-mail: skowalski.medicine@icloud.com

Wstęp. Uzyskanie powrotu spontanicznego krwi (ROSC) u poszkodowanego z zatrzymaniem krążenia jest głównym celem prowadzenia resuscytacji krążeniowo - oddechowej.

Cel. Ocena częstości przywrócenia spontanicznego krążenia (ROSC) w zależności od rytmu serca w momencie pierwszej analizy czynności elektrycznej serca.

Materiał i metody. Analiza 105 przypadków nagłego zatrzymania krążenia w warunkach na terenie funkcjonowania brzozowskiego pogotowia ratunkowego w okresie od września 2016 do końca lutego 2018. Dane zostały pozyskane z Kart Zlecenia Wyjazdu oraz Kart Medycznych Czynności Ratunkowych (KMCR). Analizy statystycznej dokonano przy użyciu programu STATISTICA. Istotność statystyczną przyjęto na poziomie $p<0,05$.

Wyniki. Nagłe zatrzymanie krążenia w analizowanej grupie w 62,9\% dotyczyło mężczyzn. Powrót spontanicznego krążenia udało uzyskać się w 16 z 105 (15,2\%) przypadków pozaszpitalnego zatrzymania krążenia. Analiza wykazała, że ROSC udało osiągnąć się, aż u 66,67\% pacjentów, którzy podczas pierwszej analizy rytmu reprezentowali zatrzymanie krążenia w mechanizmie VF/pVT, co stanowiło 75\% wszystkich przypadków ROSC w przeanalizowanej grupie. Zestawienie między ROSC, a rytmem w czasie pierwszej oceny rytmu, wykazało istotną zależność $(p=0,00)$. Wykazano również znaczącą statystycznie zależność pomiędzy ROSC, a średnim wiekiem pacjenta $(p=0,0155)$.

Wnioski. Nagłe zatrzymanie krążenia w czasie, którego podczas pierwszej analizy rytmu stwierdzono VF/pVT, ma zdecydowanie większe szanse na powrót spontanicznego krążenia niż ma to miejsce w pozostałych rytmach.

Słowa kluczowe: zawał serca, resuscytacja, nagły powrót krążenia

Introduction. Return of spontaneous circulation (ROSC) of a patient with cardiac arrest is the main goal of carrying out cardiopulmonary resuscitation.

Aim. Evaluation of frequency of return of spontaneous circulation depending on the heart rhythms in the first moment of heart electrical activity.

Material and methods. Analysis of 105 cases of sudden cardiac arrest in out-of-hospital conditions on the premises of Brzozow Emergency Medical Service from September 2016 to the end of February 2018. The data was collected from intervention medical cards and medical rescue procedure cards. Statistical analysis was carried out using STATISTICA software. Statistical significance was assumed to be $p<0.05$. 
Results. Sudden cardiac arrest in the analysed group applied to $62.9 \%$ of men. Return of spontaneous circulation was achieved only in 16 out of 105 cases (15.2\%) of sudden cardiac arrest. The analysis has indicated that ROSC was successful among $66.67 \%$ of patients, who during the first analysis of the rhythm, represented cardiac arrest in VF/pVT, what constituted 75\% of all ROSC cases in the analysed group. Comparison between ROSC and rhythm during the first evaluation of the rhythm showed statistical significance $(p=0.00)$. Statistical significance was also shown in the relationship between ROSC and the average age of the patient $(p=0.0155)$. Conclusions. Sudden cardiac arrest, when diagnosed in the first analysis of the rhythm VF/pVT, has bigger chances for return of spontaneous circulation than it has in other rhythms.

Key words: $\quad$ cardiac arrest; resuscitation; return of spontaneous circulation

\section{INTRODUCTION}

Sudden cardiac arrest is a ceasing of flow of the blood in the body associated with apnoea and lack of response from the patient. It is caused by heart's ineffective mechanical activity or its total cessation. Sudden cardiac arrest is a serious problem because it is one of the most common death causes in Europe. In the US, 350000 incidents of out-of-hospital cardiac arrest (OHCA) happen every year. In Europe, this problem encounters 350000 - 700000 people every year. Mechanisms that cause sudden cardiac arrest can be divided into two groups: non-defibrillating rhythm - asystole and pulseless electrical activity (PEA) and defibrillating rhythm - ventricular fibrillation (VF) and pulseless ventricular tachycardia (pVT) [1,2]. Mechanism which leads to sudden cardiac arrest determine the proceeding, which is to be undertaken by the people applying advanced cardiopulmonary resuscitation $[3,4]$. All the actions carried out during the rescue activities are aimed to return of spontaneous circulation (ROSC) and increase the chances of survival till release from the hospital $[1,2]$. ROSC is the priority during cardiopulmonary resuscitation, that is why what is worth considering are the variables which contribute to sudden cardiac arrest and their impact on chances of return of spontaneous circulation.

\section{AIM}

The objective of this research was the evaluation of frequency of ROSC depending on the heart rhythm during the first analysis of heart electrical activity carried out by emergency medical service in out-of-hospital conditions.

\section{MATERIALS AND METHODS}

Retrospective research was carried out based on 105 cases of sudden cardiac arrest, which happened in out-of-hospital conditions on the Brzozow Emergency Medical Service premises. Analysed cases in this research of sudden cardiac arrest happened between September 2016 and the end of February 2018. In order to collect data, intervention MET cards and emergency medical services form filled by emergency services were used. Collected quantitative and qualitative data was analysed using STATISTICA Software 12. Statistical significance was assumed at $\mathrm{p}<0.05$.

\section{RESULTS}

There were 66 men (62.9\%) and 39\% women (37.1\%) in the analysed group. The age range varied between 20 and
98 years with the average age 70.5 and standard deviation was equal to 15.8 . Only one in every four patients was not older than 61 years. The place of incident where sudden cardiac arrest usually happened was home $n=93 ;(88.6 \%)$, and the person who called emergency service was stated in intervention MET as others $(n=67 ; 63.8 \%)$. Median of the time of arrival to the place of the accident was 11 minutes (mean=13.6; $\mathrm{SD}=7.9$ ) and the average distance covered by EMS was $10.2 \mathrm{~km}$ (SD=7.7). Out-of-hospital rhythm of cardiac arrest during the first analysis of heart electrical activity in 66 cases was asystole/PEA (62.9\%), in 21 cases the rhythm was determined as unknown (20.0\%) and in 18 cases CF/VT (17.1\%). The average age of the patients in combination with determined rhythm during the first analysis was as follows: for asystole/ PEA 7 [2,3], 7 years $(\mathrm{SD}=13.9), \mathrm{VF} / \mathrm{VT} 63.5$ years $(\mathrm{SD}=18.0)$ and for rhythms determined as unknown 66.8 years $(\mathrm{SD}=17.6)$ (Table 1$)$.

Tab. 1. Cardiac arrest rhythm in the first analysis, age, time of arrival of emergency medical service (EMS) and distance to the place of incident

\begin{tabular}{|c|c|c|c|c|c|}
\hline \multicolumn{6}{|c|}{ Age } \\
\hline $\begin{array}{c}\text { Cardiac arrest } \\
\text { rhythm after first } \\
\text { analysis }\end{array}$ & Average & $\begin{array}{l}\text { Standard } \\
\text { deviation }\end{array}$ & Q25 & Median & Q75 \\
\hline Asystole /PEA & 73.7 & 13.9 & 63 & 76 & 86 \\
\hline VF/NT & 63.5 & 18 & 59 & 62.5 & 79 \\
\hline Unknown & 66.8 & 17.6 & 55 & 71 & 81 \\
\hline Overall & 70.5 & 15.8 & 61 & 73 & 82 \\
\hline Statistical analysis & \multicolumn{5}{|c|}{$H(2, N=105)=5.8801$} \\
\hline \multicolumn{6}{|c|}{ Time of arrival of emergency medical service } \\
\hline $\begin{array}{c}\text { Cardiac arrest } \\
\text { rhythm after first } \\
\text { analysis }\end{array}$ & Average & $\begin{array}{l}\text { Standard } \\
\text { deviation }\end{array}$ & Q25 & Median & Q75 \\
\hline Asystole /PEA & 14.5 & 8.6 & 9.0 & 12 & 20 \\
\hline VF/VT & 13.9 & 8.2 & 7.0 & 11.5 & 20 \\
\hline Unknown & 10.5 & 4.8 & 7.0 & 9 & 14 \\
\hline Overall & 13.6 & 8 & 8.0 & 11 & 18 \\
\hline Statistical analysis & \multicolumn{5}{|c|}{$H(2, N=105)=3.8307$} \\
\hline \multicolumn{6}{|c|}{ Distance from the place of incident } \\
\hline $\begin{array}{c}\text { Cardiac arrest } \\
\text { rhythm after first } \\
\text { analysis }\end{array}$ & Average & $\begin{array}{l}\text { Standard } \\
\text { deviation }\end{array}$ & Q25 & Median & Q75 \\
\hline Asystole /PEA & 10.8 & 7.6 & 5 & 10 & 15 \\
\hline VF/VT & 12.1 & 9.7 & 6 & 11.5 & 15 \\
\hline Unknown & 6.8 & 4.5 & 3 & 6 & 10 \\
\hline Overall & 10.2 & 7.6 & 4 & 10 & 14 \\
\hline Statistical analysis & \multicolumn{5}{|c|}{$H(2, N=105)=5.0186$} \\
\hline
\end{tabular}


Sebastian Kowalski, Adrian Moskal, Karolina Żak-Kowalska, Mariusz Goniewicz

Statistical analysis correlating out-of-hospital cardiac arrest rhythm in the first analysis and patient's age indicated close to statistical significance relationship ( $\mathrm{p}=0.0529)$ of the variables. It was not proved that time of arrival of emergency service and distance from the place of incident had statistically significant ( $\mathrm{p}-0.1473 ; \mathrm{p}=0.0813$ ) impact on the rhythm present in first evaluation. ROSC was achieved only in $15.3 \%(n=16)$ cases out of all studied cases of sudden cardiac arrest in the analysed group. Strong correlation was found between ROSC and patient's age $(\mathrm{p}=0.01555)$. Return of spontaneous circulation happened with patients, whose average age was 62.1 years, whereas lack of ROSC happened with older people (72.1 years). Similarly to cardiac arrest rhythm in the first analysis, lack of/presence of ROSC did not indicate statistical significance regarding time of arrival of emergency medical service $(\mathrm{p}=0.9964)$ and distance from the place of incident $(\mathrm{p}=0.2519)$ (Table 2).

Tab. 2. Relationship between first rhythm of cardiac arrest, patients' age, time of arrival and distance to the place of incident

\begin{tabular}{|c|c|c|c|c|c|}
\hline \multicolumn{6}{|c|}{ Age } \\
\hline ROSC & Average & $\begin{array}{l}\text { Standard } \\
\text { deviation }\end{array}$ & Q25 & Median & Q75 \\
\hline Attained & 62.1 & 14.8 & 59.5 & 62.5 & 71 \\
\hline Unattained & 72.1 & 15.6 & 62 & 75 & 85 \\
\hline Overall & 70.5 & 15.8 & 61 & 73 & 82 \\
\hline Statistical analysis & \multicolumn{5}{|c|}{$Z=2.4208 \quad p=0.0155$} \\
\hline \multicolumn{6}{|c|}{ Time of arrival of emergency medical service } \\
\hline ROSC & Average & \begin{tabular}{|l|} 
Standard \\
deviation \\
\end{tabular} & Q25 & Median & Q75 \\
\hline Attained & 13.4 & 7.7 & 8 & 11.5 & 20 \\
\hline Unattained & 14.4 & 9.6 & 6 & 11 & 17 \\
\hline Overall & 13.6 & 8 & 8 & 11 & 18 \\
\hline Statistical analysis & \multicolumn{5}{|c|}{$Z=-0.0045$} \\
\hline \multicolumn{6}{|c|}{ Distance from the place of incident } \\
\hline ROSC & Average & \begin{tabular}{|l|} 
Standard \\
deviation \\
\end{tabular} & Q25 & Median & Q75 \\
\hline Attained & 9.6 & 6.8 & 4 & 9 & 14 \\
\hline Unattained & 13.5 & 10.9 & 4.5 & 12 & 17.5 \\
\hline Overall & 10.2 & 7.7 & 4 & 10 & 14 \\
\hline Statistical analysis & \multicolumn{5}{|c|}{$Z=-1.1457 \quad p=0.2519$} \\
\hline
\end{tabular}

ROSC was achieved when first evaluation of out-of-hospital cardiac arrest showed asystole /PEA only in $6.1 \%$ $(n=4)$ cases. Regarding rhythms which indicated defibrillation - VF/pVT percentage increased to $66.7 \%(n=12)$. For the rhythm classified by emergency service as unknown none case was indicated for ROSC $(n=0)$. Statistical analysis showed strong relationship $(\mathrm{p}=0.0000)$ between achieving ROSC and the rhythm present in the first analysis of heart electrical activity (Table 3).
Tab. 3. Relationship between the first rhythm of cardiac arrest and return of spontaneous circulation

\begin{tabular}{|c|c|c|c|c|c|c|}
\hline \multirow{3}{*}{\begin{tabular}{|c|}
$\begin{array}{c}\text { First rhythm of } \\
\text { cardiac arrest }\end{array}$ \\
Asystole/PEA
\end{tabular}} & \multicolumn{6}{|c|}{ ROSC } \\
\hline & \multicolumn{2}{|c|}{ Attained } & \multicolumn{2}{|c|}{ Unattained } & \multicolumn{2}{|c|}{ Overall } \\
\hline & 4 & 6.1 & 62 & 93.9 & 66 & 62.9 \\
\hline VF/VT & 12 & 66.7 & 6 & 33.3 & 18 & 17.1 \\
\hline Uknown & 0 & 0 & 21 & 100 & 21 & 20 \\
\hline Statistical Analysis & \multicolumn{6}{|c|}{$\mathrm{Chi}^{2}=44.9387 \quad \mathrm{df}=2 \quad \mathrm{p}=0.0000$} \\
\hline
\end{tabular}

\section{DISCUSSION}

The analysis of out-of-hospital cases of cardiac arrest indicated that on the Brzozow county premises between September 2016 and end of February 2018, the most common rhythm for sudden cardiac arrest in the first analysis of heart electrical activity was asystole/PEA $62.9 \%$. Patients, who were diagnosed with VF/pVT, constituted $17.1, \%$, what was the result similar to Graesner's and Nadolny's results $[5,6]$. The analysis of the above results showed decrease in frequency of $\mathrm{VF} / \mathrm{pVT}$ in sudden cardiac arrest in out-of-hospital conditions observed in Poland and Europe [7-9]. Carried out analysis, which has taken into consideration mechanism of cardiac arrests and patients' age, showed statistical significance. Elderly people were more frequently diagnosed with sudden cardiac arrest in non-defibrillation rhythms (Asystole/PEA - 73.7 years), whereas younger patients were diagnosed with sudden cardiac arrest in defibrillation rhythm (VF/ VT -63.5 years). Similar results were presented by Wolibinski in his research [10]. Retrospective research was carried out on rural area. The research group was dominated by patients, who did not achieve return of spontaneous circulation $(84.7 \%)$.

However $15.3 \%$ of cases service on the even site turned out to be efficient and led to return of spontaneous circulation. Such a low percentage was observed in rural areas, whereas an increase in ROSC was observed in town and cities $[6,11]$. Taking into consideration return of spontaneous circulation and patients' age, the carried-out analysis showed statistically significant difference. ROSC was usually achieved for younger people (62.1, years). Resuscitation at elderly patients usually ended up with no success. The difference was showed also by Graesner in his research at patients with out-of-hospital cardiac arrest [12]. Correlation between distance and time of arrival to the accident place and ROSC did not show statistical significance. Time of arrival to the accident place was $11.5 \mathrm{minu}$ tes and it was shorter than time of arrival to the accident place out of Rzeszow city county [13]. ROSC was achieved when first analysis of sudden cardiac arrest rhythm indicated asystole/PEA only in $6.1 \%(\mathrm{n}=4)$ cases.

Regarding rhythms which were an indication for defibrillation $\mathrm{VF} / \mathrm{pVT}$ the percentage increased to $66.7 \%$ $(n=12)$. Other authors' results present chances for achieving ROSC in defibrillation rhythms on the level between $50.6 \%$ and $64.5 \%[14,15,16]$. Statistical analysis showed strong relationship $(\mathrm{p}=0.0000)$ between ROSC and rhythm present in the first analysis of heart electrical activity. 


\section{CONCLUSIONS}

1. Return of spontaneous circulation appears more frequently in VF/pVT rhythms than at patients with cardiac arrest mechanism of asystole and PEA.

2. Age of the patient is directly related to the chances for return of spontaneous circulation. ROSC is achieved more often at younger people.

\section{REFERENCES}

1. Kamińska K, Krzemińska S. A nursing care of patients after cardiac arrest in the course of myocardial infarction. Journal of Education, Health and Sport. 2018;8(7):345-356.

2. Soar J, Nolan JP, Böttiger BW, et al. European Resuscitation Council Guidelines for Resuscitation 2015 Section 3. Adult advanced life support Resuscitation. 2015;95:100-147.

3. Perkins GD, Olasveengen TM, Maconochie I, et al. European Resuscitation Council guidelines for resuscitation: 2017 update. Resuscitation. 2018;123:43-50.

4. Sondergaard MM, Nielsen JB, Mortensen RN, et al. Associations between common ECG abnormalities and out-of-hospital cardiac arrest. British Medical Journal. 2019;6.

5. Gräsner JT, Bossaert L. Epidemiology and management of cardiac arrest: what registries are revealing. Best Pract Res Clin Anaesthesiol. 2013;27(3):293-306.

6. Nadolny K, Bujak K, Kucap M, et al. The Silesian Registry of Out-of-Hospital Cardiac Arrest: Study design and results of a three-month pilot study. Cardiology Journal. Published online: 2018-11-14; D0I: 10.5603/CJ.a2018.0140.

7. Keller SP, Halperin HR. Cardiac arrest: the changing incidence of ventricular fibrillation. Current Treatment Options in Cardiovascular Medicine. 2015;17(7):392.

8. Strömsöe A, Svensson L, Axelsson AB, et al. Improved outcome in Sweden after outof-hospital cardiac arrest and possible association with improvements in every link in the chain of survival. European Heart Journal. 2015;36(14):863-871.

9. Hulleman M, Zijlstra JA, Beesems SG, et al. Causes for the declining proportion of ventricular fibrillation in out-of-hospital cardiac arrest. Resuscitation. 2015;96:2329.

10. Wolbinski M, Swain AH, Harding SA, Larsen PD. Out-of-hospital cardiac arrest patient characteristics: comparing ventricular arrhythmia and Pulseless Electrical Activity. Heart Lung and Circulation. 2016;25(7):639-644.

11. Cebula $G, 0$ sadnik $S$, Wysocki M, et al. Comparison of the early effects of out-ofhospital resuscitation in selected urban and rural areas in Poland. A preliminary report from the Polish Cardiac Arrest Registry by the Polish Resuscitation Council. Kardiologia Polska. 2016;74(4):356-361.

12. Gräsner JT, Meybohm P, Lefering R, et al. ROSC after cardiac arrest - the RACA score to predict outcome after out-of-hospital cardiac arrest. European Heart Journal. 2011;32(13):1649-1656.

13. Filip D, GórskiA, WojtaszekM, Ozga D. Analiza funkcjonowaniazespołów ratownictwa medycznego w rejonie operacyjnym Wojewódzkiej Stacji Pogotowia Ratunkowego w Rzeszowie w 2012 roku. Anestezjologia i Ratownictwo. 2016;10:278-285.

14. Rosell-Ortiz F, Escalada-Roig X, Fernandez Del Valle P, et al: Out-of-hospital cardiac arrest $(\mathrm{OHCA})$ attended by mobile emergency teams with a physician on board. Results of the Spanish OHCA Registry (OSHCAR). Resuscitation. 2017;113:90-95.

15. Hiltunen $P$, Kuisma $M$, Silfvast $T$, et al. Regional variation and outcome of out-ofhospital cardiac arrest $(\mathrm{OHCA})$ in Finland - the Finnresusci study. Scandinavian Journal of Trauma, Resuscitation and Emergency Medicine. 2012;20:80.

16. Nadolny K, Szarpak L, Gotlib J, et al: An analysis of the relationship between the applied medical rescue actions and the return of spontaneous circulation in adults with out-of-hospital sudden cardiac arrest. Medicine (Baltimore). 2018;97(30): e11607.

Manuscript received: 16.08 .2019

Manuscript accepted: 01.09.2019

Translation: Sebastian Kowalski 